\title{
Violence in the Lives of Children
}

By Brett V. Brown, Ph.D, and Sharon Bzostek, Child Trends

Violence is a part of every child's life in America. Violence originates in many places - self, family, peers, the community, and the media - and violence affects children and youth at every age, even the newborn. Children and youth are witnesses and victims, and some become perpetrators. All are affected, though not all are affected equally.

Much of the reporting on violence in children's lives focuses narrowly on a particular type: child abuse or media violence, gang violence or suicide, dating violence or violent crime. In contrast, this data brief presents a broad overview of the incidence of many types of violence affecting the lives of children and youth. This approach provides a stronger sense of the relative risks for children experiencing different forms of violence, as well as disparities in the overall levels of violence experienced by different groups of children: male and female; black, white, and Hispanic; younger and older.

Programs and policy making related to violence in children's lives are often also focused narrowly on particular types of violence. The broader picture sketched out in this brief may help policy makers and service providers to prioritize program and funding efforts and to design anti-violence interventions that are more sensitive to the broad needs of target groups.

The brief begins by presenting information on many types of violence that affect children's lives, grouped by the frequency with which they occur. It draws on the latest data and the most recent findings from research studies to look, first, at the most common forms of violence affecting children and youth; next, at the least common forms of violence affecting children and youth; and, then, at a variety of other types of violence that can have an effect on how wellor how poorly - children and youth develop. ${ }^{1}$ The brief then focuses on the critical intersections of violence and age, gender, and race/ethnicity by examining how various subgroups of children and youth are affected by violence. Finally, the brief considers the need to collect other types of information to help monitor and track violence in the lives of America's children and youth.

This is the first of a series of data briefs produced for the Child Trends DataBank. The title of the series CrossCurrents - reflects the intent of these briefs. That intent is to look across a number of individual indicators of child well-being, drawn from the DataBank and other sources, to illuminate a broad theme relating to the lives of children and youth. The briefs will focus on topics of greatest contemporary concern to policy makers, service providers, the media, and the general public. The topic of this inaugural brief clearly merits such concern: violence in the lives of children.

Child Trends is grateful to the David and Lucile Packard Foundation for its support of these briefs and for its overall support of the Child Trends DataBank. Additional support for the DataBank has been provided by the Foundation for Child Development, the Edna McConnell Clark Foundation, and the John S. and James L. Knight Foundation. 


\begin{tabular}{|c|c|c|c|c|}
\hline \multicolumn{5}{|l|}{ Table 1} \\
\hline \multicolumn{5}{|c|}{ Prevalence of Different Forms of Violence in the Lives of Children and Youth } \\
\hline Type of Violence & Year & \begin{tabular}{|c|} 
Ages \\
\end{tabular} & Percent & Frequency \\
\hline $\begin{array}{l}\text { Watches } 2+\text { hours of TV (each } \\
\text { weekday) }\end{array}$ & 2001 & 8th Grade & 73.1 & Nearly 3 out of 4 \\
\hline Physical fighting (past year) & 2001 & Grades 9-12 & 33.2 & 1 out of 3 \\
\hline $\begin{array}{l}\text { Parents who report spanking with } \\
\text { hard object (past year) }\end{array}$ & 1995 & $\begin{array}{l}\text { Children ages 2- } \\
17\end{array}$ & 21 & 1 out of 5 \\
\hline Weapons carrying (past month) & 2001 & Grades 9-12 & 17.4 & 1 out of 6 \\
\hline $\begin{array}{l}\text { Domestic violence exposure (past } \\
\text { year) }\end{array}$ & 1979,1985 & Under age 18 & $5-16$ & $\begin{array}{l}1 \text { out of } 20 \text { - } \\
1 \text { out of } 6\end{array}$ \\
\hline Teen suicide attempts (past year) & 2001 & Grades 9-12 & 8.8 & 1 out of 11 \\
\hline Bullying (past six months) & 2001 & Ages 12-18 & 7.9 & 1 out of 13 \\
\hline $\begin{array}{l}\text { Fear of attack at school }{ }^{3} \text { (past six } \\
\text { months) }\end{array}$ & 2001 & Ages 12-18 & 6.4 & 1 out of 16 \\
\hline $\begin{array}{l}\text { Violent crime victimization (past } \\
\text { year) }\end{array}$ & 2001 & Ages 16-19 & 5.6 & 1 out of 18 \\
\hline $\begin{array}{l}\text { Violent crime victimization (past } \\
\text { year) }\end{array}$ & 2001 & Ages 12-15 & 5.5 & 1 out of 18 \\
\hline Child maltreatment $^{4}$ (past year) & 2001 & Under age 18 & 1.2 & 1 out of 83 \\
\hline Sexual abuse (past year) & 2001 & Under age 18 & 0.12 & 1 out of 833 \\
\hline Teen homicide (annual) & 2000 & Ages 15-19 & 0.0096 & 1 out of 10,417 \\
\hline Teen suicide (annual) & 2000 & Ages 15-19 & 0.0082 & 1 out of 12,195 \\
\hline Infant homicide $^{5}$ (annual) & 2001 & Under one year & 0.0077 & 1 out of 12,987 \\
\hline \multicolumn{5}{|c|}{$\begin{array}{l}{ }^{1} \text { The lower bound estimate of domestic violence is from } 1979 \text {, with percent of total population calculated using population } \\
\text { estimates for July of } 1980 \text { from the U.S. Census Bureau. The upper bound estimate is from 1985, with percent of total population } \\
\text { calculated using population estimates for July of } 1985 \text { from the U.S. Census Bureau. }\end{array}$} \\
\hline \multicolumn{5}{|c|}{$\begin{array}{l}{ }^{2} \text { Because the lower bound (1979) estimate for domestic violence is based on a sample of } 3-17 \text { year olds living in two-parent } \\
\text { families, it is likely that the actual prevalence of domestic violence is greater than the estimate presented here. }\end{array}$} \\
\hline \multicolumn{5}{|c|}{${ }^{3}$ Includes fear of attack at school or on the way to and from school } \\
\hline \multicolumn{5}{|c|}{${ }^{4}$ Includes physical abuse, sexual abuse, neglect, and emotional maltreatment } \\
\hline${ }^{5} 2001$ data for infant homicide are preliminary & & & & \\
\hline
\end{tabular}

\section{The Most Common Forms}

\section{OF ViOLENCE}

(See Figure 1)

\section{Media Violence}

Most children are exposed to media violence at some level on a daily basis through television, video games, or music. Nearly threequarters of all eighth-graders report that they watch two or more hours of television each weeknight, and a third report that they watch four or more hours each weeknight. ${ }^{2}$ (See Table 1.)

According to the American Psychiatric Association, the average American child watches 28 hours of television each week and will have seen 16,000 simulated murders and 200,000 acts of violence by the age of 18 . Prime-time programming for adults is far less violent than commercial television for children. Some cartoons, for example, include more than 80 violent acts per hour. ${ }^{3}$ Research has demonstrated a link between exposure to violence in the media and several negative outcomes for children, including increased aggressive behavior and attitudes, fears or pessimistic attitudes about the world, and desensitization to both real and fantasy violence. ${ }^{4}$ Exposure to media violence has also been associated with increased depression, nightmares, and sleep disturbances. ${ }^{5}$ Moreover, children who identify with aggressive characters on television and who perceive television violence as real are more likely to be aggressive as adults, regardless of how aggressive they were as children. ${ }^{6}$

\section{Physical Fighting}

Physical fighting is a remarkably common event in the lives of youth. In 2001, one-third 
of all high-school students reported being in a physical fight within the last year. ${ }^{7}$ About four percent - not an inconsequential proportion - required treatment by a doctor or a nurse because of their resulting injuries. ${ }^{8}$ Further, about one in ten high-school students reported having been physically hurt on purpose by a boyfriend or girlfriend within the past year. ${ }^{9}$

\section{Severe Spanking}

Spanking is a broadly accepted and commonly used tool of discipline, particularly for young children. There is considerable disagreement in practice and research as to when spanking can be a constructive form of discipline and when it may cause problems for children beyond the immediate pain of the event. We consider it in this brief because severe spanking can, according to some research, be harmful to children.

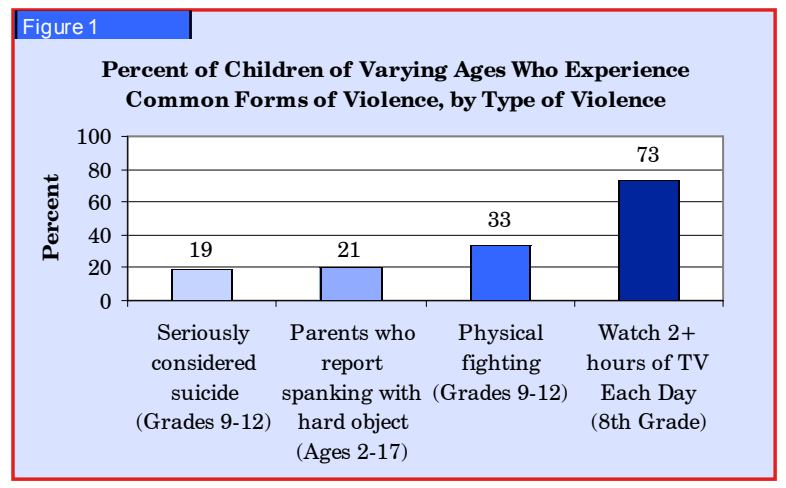

In a recent survey, more than 70 percent of adults agreed that it was sometimes necessary to discipline a child "with a good, hard spanking."10 Another survey from 1995 indicated that more than 70 percent of parents of children between the ages of two and eight had spanked their children (on the bottom with a bare hand) within the last year. Spanking as a tool of discipline declines to 43 percent for parents of children ages nine through 12, and to 14 percent for parents of teens ages 13 to 17. About one-third of parents of children under age two reported spanking in the past year. ${ }^{11}$
Severe forms of spanking involving a belt, hairbrush, stick, or some other hard object are less common than spankings administered by hand. About 21 percent of parents of children under age 18 reported spanking their child with an object at least once in the past year, while 47 percent reported spanking with an open hand during the past year. ${ }^{12}$

Research on the effects of spanking on children is mixed. Many studies show consistent relationships between corporal punishment and increased problems with aggression, depression, juvenile delinquency, and even later spousal abuse. ${ }^{13}$ These findings have led one leading researcher on violence towards children to argue that parents should always be discouraged from spanking children in favor of nonviolent forms of correction that can be equally or more effective. ${ }^{14}$ Other prominent researchers have found that mild to moderate spanking was not associated with lasting harm to the child once other aspects of the parent/child relationship were taken into account. 15

\section{Carrying Weapons}

Data show that a substantial minority of youth carry a weapon, such as a gun, knife, or club. In 2001, more than 17 percent of all high-school students reported carrying a weapon within the past month, and nine percent reported being threatened with a weapon on school property within the past year. ${ }^{16}$ (See Table 1.)

\section{Contemplating Suicide}

While it is rare for children and youth to actually kill themselves, it is not at all rare for them to think about doing so. In 2001, nearly one in five (19 percent) high-school students reported that they had thought seriously about killing themselves within the last 12 months, and about one in 11 (9 percent) reported actually attempting suicide. 17 Reliable national estimates are not available for younger children. 
The Least Common Forms OF Violence

(See Figure 2)

While the death of a child is tragic, statistically, death is an uncommon outcome of violence for children and youth. Headline-grabbing incidents to the contrary, many people may not realize how infrequent it is for violence to end a young person's life. In 2000, for example, one in 10,417 teens between the ages of 15 and 19 was murdered, and one in 12,195 committed suicide. ${ }^{18}$ Assuming teens face this risk each year from ages 15 to 19 , fewer than one in 1,100 will die by homicide or suicide while in this age range. These overall rates do mask considerable differences in risk across race and ethnic groups, however. To take a particularly dramatic example, in 2000, homicide rates among black males ages 15 to19 were more than three times as high as the overall rates for all males in that age group. 19

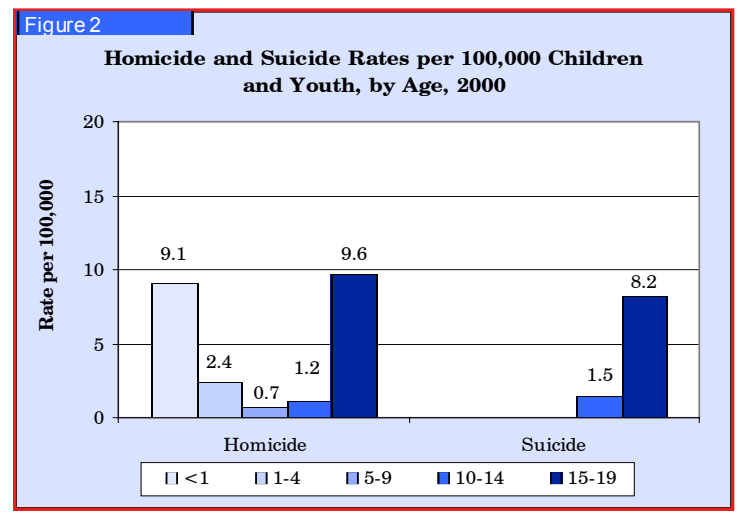

In 2000 , children between the ages of 10 and 14 had homicide and suicide rates that were less than one-fifth the rates for youth between the ages of 15 and 19.20 Homicide rates for children below the age of 10 were also very low, with the surprising exception of infants, whose chances of being murdered were one in $12,987.21$

Although violent death is a relatively rare occurrence among children and youth overall, the costs in terms of anguish, lost potential, and lost productivity are, of course, much higher than other violence-related outcomes. Analyses show that the average teen who dies today loses about 60 years of life. ${ }^{22}$ And, though rare, homicide is still the second leading cause of death among teens ages 15 to 19.23 It doesn't take sophisticated data analysis to know that even one death of a child or teenager by violence is one death too many.

\section{OTHER Forms OF ViOLENCE}

\section{Domestic violence}

Little reliable data exist on the percentage of children who live in households in which domestic violence occurs. Data from the late 1970 s estimate that at least 3.3 million children were exposed to domestic violence each year. $^{24}$ Estimates from a 1985 survey indicate that as many as 10 million children were exposed to physical violence of some sort between their parents. ${ }^{25}$ Surprisingly, more recent estimates are not available.

(See Table 1.)

Compared with children in other households, children who have been exposed to domestic violence often suffer from insomnia and have trouble with bed-wetting. They also are more likely to experience difficulties in school and to score lower on assessments of verbal, motor, and cognitive skills. ${ }^{26}$ Also, they are more likely than other children to exhibit aggressive and antisocial behavior, to be depressed and anxious, and to have slower cognitive development. ${ }^{27}$ Finally, in a disturbingly prophetic pattern, recent research indicates that males exposed to domestic violence as children are more likely to engage in domestic violence as adults, and females are more likely to be victims as adults. ${ }^{28}$

\section{Child abuse and neglect}

In 2001, 903,000 cases of child abuse and neglect (collectively known as "child maltreatment") were reported to and substantiated by child welfare authorities, or a little more than one case for every 100 U.S. children under age 18. (See Table 1.) The rate of physical abuse is much lower, at about two-tenths of one percent (the balance being incidences of neglect, sexual abuse, and psychological maltreatment). ${ }^{29}$ 
However, these estimates probably substantially underestimate the number of children who are physically abused by parents or other adults in their household because many incidents are never reported to authorities, either because they are not detected or not deemed serious enough to warrant further investigation. Data from a 1995 national survey indicate that six percent of mothers and three percent of fathers reported that they had ever physically abused their child. ${ }^{30}$ The survey asked about specific forms of physical abuse, such as hitting, kicking, beating, choking, or even burning a child. Given the sensitivity of the questions and the stigma associated with being a perpetrator of child abuse, parents may well have been underreporting such behavior.

Victims of child maltreatment may experience both immediate fear and bodily harm and more long-term consequences, such as poor school performance, learning disorders, poor peer relations, and antisocial behavior. Children who have been abused are also at higher risk for long-term health problems, including mental retardation, speech problems, physical defects, and mental health disorders. 31

\section{Sexual Abuse and Assault}

According to the National Child Abuse and Neglect Data System (NCANDS), there were 86,830 substantiated cases of sexual abuse in 2001 - or 0.1 percent of the population under the age of $18 .{ }^{32}$ (See Table 1.)

Survey data, however, indicate that the overall risk of sexual assault is much higher. ${ }^{33}$ For example, a national survey that was conducted in 2001 found that 7.7 percent of students in grades nine through twelve reported having been raped at some point in their lives. ${ }^{34}$

Children and adolescents who have been sexually abused may experience various psychological and behavioral problems, such as guilt, fear, sexual dysfunction, withdrawal, and acting out. 35 Victims of rape sometimes have to cope with immediate consequences - pregnancy or sexually transmitted diseases, for example - as well as more long-term consequences, such as eating disorders, sexual dysfunction, sleep disturbances, and chronic headaches and fatigue. ${ }^{36}$

\section{Violent Crime Victimization}

In 2001, 5.5 percent of youth between the ages of 12 and 15 and 5.6 percent of youth between the ages of 16 and 19 reported being victims of violent crime during the year (data are not available for children under age 12). The most common form of violent crime was simple assault, though aggravated assault, robbery, and sexual assault are also included in the violent crime category. 37 (See Table 1.) These rates are substantially higher than among older age groups.

\section{The Age Factor}

As children age, the types of violence they face, the sources of violence, and the risk of violence all change.

\section{INFANTS AND YOUNG CHILDREN}

For very young children, the primary locus of violence is the home. Children under the age of eight are about as likely as older children to be reported to the child welfare system as victims of physical abuse. ${ }^{38}$ The health consequences of this abuse, however, can be worse for the youngest children. Infants who are abused can suffer permanent brain damage from shaken baby syndrome. ${ }^{39}$ The most tragic outcome of abuse against infants, of course, is death. And here the statistics tell a shocking story: the homicide rate for infants is higher than for any age group up until age 17.40 In 2001, 40.9 percent of deaths resulting from child abuse and neglect were among children under the age of one, and 84.5 percent were among children under age 6.41 Perpetrators are almost always a parent or other relative. ${ }^{42}$

Very young children are more likely than older children to be exposed to domestic violence. ${ }^{43}$ Research indicates that this exposure can have negative consequences even for infants and toddlers, belying the notion that 
they are too young to know "what's going on." For example, infants and toddlers who are exposed to domestic violence may experience increased listlessness, failure to thrive, and problems with trust. 44

Data from 1995 indicate that about one-third of parents of children under the age of two report spanking (with the hand) within the previous year. This represents a lower rate than that for parents of children between the ages of two and eight (more than 70 percent) and for parents of children between the ages of nine and 12 (43 percent), but spanking is still common among very young children. ${ }^{45}$ Again, we emphasize that spanking can range from a mild swat to a severe hit, and research is mixed as to when spanking can be beneficial, and when it is harmful for children.

Young children (ages two through seven, in this case) are less exposed to media violence than older children, but data collected in 1999 show that they still spend more than three hours each day watching television and videos. 46

\section{MidDle CHILDHOOD}

\section{(ABOUT AGES 7 TO 12)}

Children in middle childhood watch more television and are therefore, presumably, more exposed to television violence than children who are younger or older. ${ }^{47}$ Rates of reported physical abuse are about the same for children in middle childhood as for younger children. ${ }^{48}$

Rates of homicide and suicide are very low in middle childhood. For example, year 2000 estimates for children between the ages of 10 and 14 show risks of about one in 100,000 for both homicide and suicide - or 0.001 percent. Homicide rates are even lower for children between the ages of five and nine, and suicide is practically unheard of for this age group (seven cases for the entire U.S. in 2000). 49

Surprisingly, national data on peer violence (such as bullying and engaging in physical fights) are almost totally unavailable for this age group. Some limited data exist, though, on sixth-graders, most of whom are 12 years old. These data indicate that the chances of being bullied in school are higher for sixthgraders than for any other group through grade 12.50 The fear of attack at school or on the way to or from school is also higher for this age group than for older adolescents. ${ }^{51}$ (See Figure 3.)

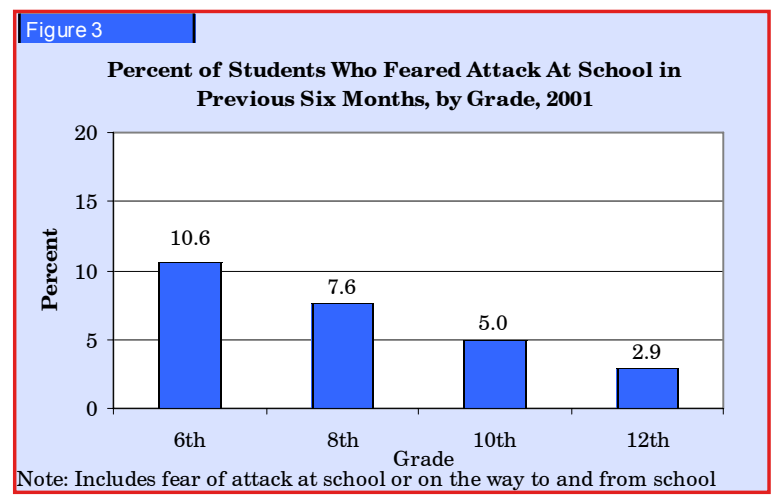

\section{TeEnagers}

Many people believe that violence towards children reaches its peak in the lives of teenagers. While this is true for some of the more extreme forms of violence, other types of violence actually begin to recede during the teenage years.

Homicide and suicide rates do increase rapidly throughout the teen years. Between the ages of 15 and 19, estimates for 2000 indicate that the homicide rate increased from 3.8 to 15.8 for every 100,000 teenagers, and the suicide rate increased from 4.7 to 10.6 for every 100,000 teenagers. ${ }^{52}$ The risk of being a victim of sexual assault, aggravated assault, and robbery also increases as teens get older. ${ }^{53}$

A substantial minority of teens carry a weapon. One in six high-school students (17 percent) reported that he (mainly) or she carried a weapon one or more times in the previous month in 2001.54 These rates are presumably much higher than the rate one would see among middle- and grade-school students, though estimates are not available for these age groups.

Violence associated with dating is also fairly common during the teen years. In 2001, 
nearly 10 percent of teens in grades nine through 12 reported that they had been hit, slapped, or otherwise physically hurt on purpose by a boyfriend or girlfriend within the past year. ${ }^{55}$ The risk is slightly higher for older students (11 percent for 12th-grade students compared with 9 percent for those in the 9 th-grade). 56

As mentioned at the outset of this section on teenagers, the risk of some forms of violence drops substantially between grades six and 12. For example, in 2001, 10.6 percent of sixth-grade students reported that they feared being attacked at school or on the way to and from school, compared with 2.9 percent of 12th-grade students. 57 (See Figure 3.) The percentage of students who reported being in physical fights also decreases with age, with 40 percent of ninth-graders in 2001 reporting they had been in a fight in the previous year, compared with 27 percent of 12 thgraders. 58

As adolescents get older, they experience some forms of home-based violence less often. For example, data for 2000 indicate that 16to 17-year-old males are less likely to suffer physical abuse in their households than younger males. Among females, physical and sexual abuse in the home peak between the ages of 12 and 15, declining somewhat between the ages of 16 and 17.59 Not surprisingly, spanking becomes a less common form of parental discipline once children become teenagers, affecting only 14 percent of those between the ages of 13 and 17.60

\section{The Gender Factor}

(See Figure 4)

The types of violence experienced by males and females are often very different, as are their relative levels of risk, though neither gender is immune from any particular form of violence. Females are much more likely at every age to be victims of sexual abuse and rape. Reports of sexual abuse to child welfare agencies are two to seven times higher for females depending on their age. ${ }^{61}$
By the time they are in high school, one in ten females reports that she has been raped in her lifetime, compared with one in 20 males. ${ }^{62}$ Female teens (ages 12 to 17 ) are also more likely than males to be victims of physical abuse in the home (though the opposite is true for children under the age of eight). ${ }^{63}$ In addition, female high-school students are nearly twice as likely as males to report attempting suicide, 64 though, as indicated below, males are far more likely to be successful in their attempts.

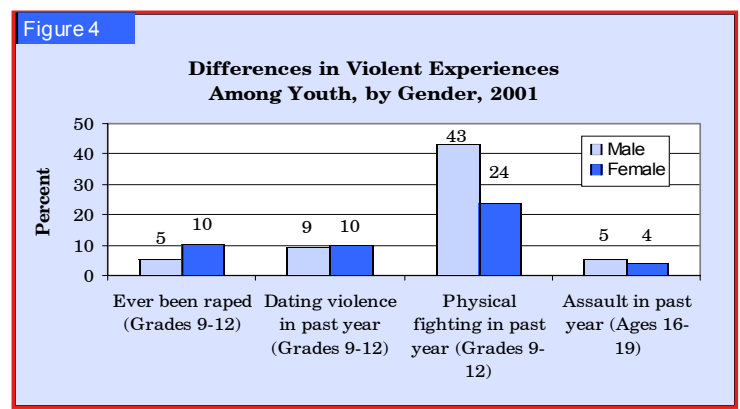

Contrary to what many people may think, male and female high-school students are about equally likely to report being victims of dating violence. 65 Research indicates, however, that females are more likely to suffer significant injury from such violence. 66

Overall, for most other types of violence, males are at much higher risk than their female counterparts. Males of every age are more likely to be victims of homicide, including male infants. 67 The gender differences become especially large among teens between the ages of 15 and 19, with males about five times more likely than females to be victims of homicide and suicide. 68

Male teens are more than four times as likely as females to report carrying a weapon, 6980 percent more likely to have been in a fight in the last year, ${ }^{70}$ nearly 50 percent more likely to experience an aggravated assault, and more than four times as likely to have been a robbery victim. ${ }^{71}$

Under the age of eight, males are more likely than females to be reported as victims of physical abuse. ${ }^{72}$ In school, males in grades six and beyond are more likely than females 
Differences in Violent Experiences By Race/Ethnicity and Type of Violence

\begin{tabular}{|c|c|c|c|c|}
\hline Type of Violence & Year & Ages & $\begin{array}{c}\text { Blacks compared to } \\
\text { Whites }{ }^{1}\end{array}$ & $\begin{array}{c}\text { Hispanics compared } \\
\text { to Whites }\end{array}$ \\
\hline Homicide & 2000 & Infants & 4.3 times as likely & 1.2 times as likely \\
\hline Homicide & 2000 & $15-19$ & 12.5 times as likely & 6.2 times as likely \\
\hline Suicide & 2000 & $15-19$ & .63 times as likely & .70 times as likely \\
\hline Aggravated Assault & 2001 & $16-19$ & 1.7 times as likely & - \\
\hline Abuse and Neglect & 1999 & Under 18 & 2.4 times as likely & 1.2 times as likely \\
\hline 4+ Hours of TV per Day & 2001 & 8th grade & 2.8 times as likely & - \\
\hline
\end{tabular}

to report having been bullied, though both sexes are about equally likely to report fearing attack at or on the way to or from school. 73

\section{THE RACE/ETHNICITY FACTOR}

(See Table 2)

The risk of violence is often substantially different for children and youth from different racial and ethnic backgrounds. Often, these differences reflect a variety of social factors including differences in income, family structure, educational level, and neighborhood characteristics. Black infants are more than four times as likely as Hispanic and nonHispanic white infants to be murdered,74 while black teens between the ages of 15 and 19 are nearly twice as likely to be murdered as Hispanic teens and about 12.5 times as likely to be murdered as non-Hispanic white teens. ${ }^{75}$

For suicide, which now claims nearly the same number of teen lives as homicide, the pattern is quite different. For example, Native American male youth between the ages of 15 and 19 are nearly twice as likely as their non-Hispanic white counterparts to commit suicide, and about three times as likely as their black, Hispanic, or Asian counterparts to do so. 76
When it comes to child abuse and neglectblack children have higher rates than nonHispanic white or Hispanic children. ${ }^{77}$ Survey data reveal similar racial disparities for parental reports of physical abuse by parents. 78

Black youth are also more likely to report being victims of aggravated assault, and much more likely to be victims of robbery, than white youth. ${ }^{79}$

Finally, data show that black children watch considerably more television than white children, suggesting that they have greater exposure to media violence. Among eighth-graders in 2001, 62 percent of black students watched four or more hours of television on an average weekday, compared with 22 percent of white students. Similarly large differences are evident for tenth- and twelfth-grade students, though the levels are lower. 80

\section{Conclusions}

Most of the policy and data collection related to violence in children's lives tends to focus on a single type of violence (such as child abuse or media violence), a particular social context (such as the family, school, or neighborhood), or a particular group (such as teens or inner-city children). While this approach produces valuable information, and is often a necessity, efforts to address the issue of violence can be enriched by understanding the many forms of violence that affect children's lives at different ages and for different demographic groups. 
This data brief brings together estimates from a wide variety of national sources to provide that broader context. By putting different types of violence experienced by children and youth side by side (see Table 1), a more accurate sense emerges of the relative risks of a child experiencing different forms of violence. So, for example, while the chances of a teen being in a physical fight in a given year are about 33 percent, 81 his or her chances of being killed in a year are about 0.0096 percent (or less than 1 in 10,000).82 This brief also sheds light on the extent to which different types of violence are more salient at different ages and across different gender and race groups, which is vital knowledge for properly targeting and designing effective violence interventions.

Putting together the information for this brief, however, revealed some critical data gaps that would be important to fill in order to monitor violence in children's lives effectively and track progress in reducing that violence over time. A list of some of the most pressing data needs includes:

- Regular and more accurate estimates of domestic violence in households in which children reside. The most recent estimates date back to the $1980 \mathrm{~s}$, and those estimates varied widely.

- Regular measures of the actual levels of physical abuse experienced in the home by children. The major source of annual data comes from an administrative data source, the National Child Abuse and Neglect Data System (NCANDS), which reports rates that are substantially smaller than the actual incidence in the population. Such estimates are difficult to obtain because of researchers' legal obligation, in most cases, to report incidents of child abuse to authorities, but it has been done in the National Family Violence Survey (last conducted in 1995). Collecting this information on a regular basis remains an important goal.

- Regular estimates of fighting, bullying, and carrying weapons among children in grade school (K-through-5). At present, such esti-

(C)2003 Child Trends mates are collected for children only in grades six and beyond. Yet we know that fighting is common at younger ages and that early aggression is related to aggression later in life. 83 These data are needed to support early interventions that may prevent violence in the teenage years.

- Regular estimates of violence among out-ofschool youth. Much of the violence data collected on teenagers is limited to the student population. School dropouts are more likely to experience many forms of violence. ${ }^{84}$ Their absence from the surveys makes estimates from these sources unreliable as a stand-in for all youth at older ages. Out-ofschool youth (which includes dropouts in the civilian population as well as many teens in detention facilities and other institutions) represent an important target population for anti-violence interventions, and yet we have very little data for these young people.

- Longitudinal surveys focusing on the causes and consequences of violence throughout childhood. Research has firmly established that children who are exposed to, experience, or engage in violence at one period in their lives are often much more likely to engage in violence as they grow older. 85 However, no nationally representative longitudinal survey currently exists that would allow researchers to estimate the risk of experiencing multiple violent outcomes over time or to examine potential cause-and-effect relationships. That is about to change, however. David Finkelhor and colleagues have just completed the first wave of the Developmental Victimization Survey, which collects data on three dozen different types of violence and crime victimization on a national sample of 2000 children ages two to 17 . They are planning annual follow-ups. Estimates from the initial wave of data should be available shortly.

Filling in these data gaps is not only a concern of researchers, but also has bearing on the more encompassing societal concern of improving the well-being of children and youth by reducing the impact of violence on their lives. Better data, quite simply, can lead to better decisions in responding to this thorny challenge. 
Note:

Brett V. Brown, Ph.D., is director of the Child Trends DataBank and of Child Trends' Social Indicators Content Area.

Sharon Bzostek is the project manager for the Child Trends DataBank and a senior research assistant at Child Trends.

The authors are grateful to Dr. David Finkelhor, Director of the Crimes Against Children Research Center and Co-Director of the Family Research Laboratory at the University of New Hampshire, for his careful review of and helpful comments on this brief.

Editor: Harriet J. Scarupa

(c) 2003 Child Trends

ISBN 0-932359-06-X

\section{Data Sources for Figures}

\section{Figure 1}

Television viewing: Child Trends. (2002). Child Trends DataBank, Table 1. Hours of television watching on the average weekday: Eighth graders, 1991-2001. Retrieved June 13, 2003, from the World Wide Web: http://www.childtrendsdatabank.org/tables/55_Table_1.htm. Original data from Monitoring the future: A continuing study of American youth conducted by Jerald Bachman and colleagues at the Survey Research Center in the Institute for Social Research at the University of Michigan; Spanking: Straus, M. and Stewart, J. (1999). Corporal punishment by American parents: National data on prevalence, chronicity, severity, and duration, in relation to child and family characteristics. Clinical Child and Family Psychology Reviews, 2(2), 55-70; Physical fighting: Child Trends. (2002). Child Trends Databank, Table 1. Physical fighting: Percentage of students in grades 9-12 who report physical fighting in the past year. Retrieved February 14, 2003, from the World Wide Web:

http://www.childtrendsdatabank.org/tables/22_Table_1.htm. Original data from the Youth Risk Behavior Survey collected by the National Center for Chronic Disease Prevention and Health Promotion, Centers for Disease Control and Prevention; Considered suicide: Child Trends. (2002). Child Trends DataBank, Table 1. Suicidal teens: Percentage of high school students who thought seriously about attempting suicide, selected years, 1990-2001. Retrieved June 9, 2003, from the World Wide Web:

http://www.childtrendsdatabank.org/tables/34_Table_1.htm. Original data from the Youth Risk Behavior Survey collected by the National Center for Chronic Disease Prevention and Health Promotion, Centers for Disease Control and Prevention.

\section{Figure 2}

Centers for Disease Control and Prevention. (2003). Web-based injury statistics query and reporting system (WISQARS) [Online]. National Center for Injury Prevention and Control, Centers for Disease Control and Prevention (producer).

From the World Wide Web: http://www.cdc.gov/ncipc/wisqars/.

Figure 3

DeVoe, J. F., Peter, K., Kaufman, P., Ruddy, S.A., Miller, A.K., Planty, M. Snyder, T.D., Duhart, D.T., and Rand, M.R. (2002). Indicators of school crime and safety (NCES 2003-009/NCJ 196753). Washington, DC: U.S. Departments of Education and Justice.

Figure 4

Rape: Child Trends. (2002). Child Trends DataBank indicator: Adolescents who have ever been raped. Retrieved June 9, 2003, from the World Wide Web: http://www.childtrendsdatabank.org/health/violence/31Rape.htm. Original data from the Youth Risk Behavior Survey collected by the National Center for Chronic Disease Prevention and Health Promotion, Centers for Disease Control and Prevention; Dating Violence: Child Trends. (2002). Child Trends DataBank indicator: Dating violence. Retrieved June 9, 2003, from the

World Wide Web: http://www.childtrendsdatabank.org/health/violence/66DatingViolence.htm. Original data from the Youth Risk Behavior Survey collected by the National Center for Chronic Disease Prevention and Health Promotion, Centers for Disease Control and Prevention; Physical fighting: Child Trends. (2002). Child Trends DataBank indicator: Physical fighting by youth.

Retrieved June 9, 2003, from the World Wide Web:

http://www.childtrendsdatabank.org/health/violence/22PhysicalFightin g.htm. Original data from the Youth Risk Behavior Survey collected by the National Center for Chronic Disease Prevention and Health Promotion, Centers for Disease Control and Prevention; Assault: U.S. Department of Justice. (2003). Criminal victimization in the United States, 2001-Statistical Tables. (NCJ 197064) Table 4. Available from the World Wide Web: http://www.ojp.usdoj.gov/bjs/pub/pdf/cvus01.pdf.

\section{Data Sources for TABLes \\ Table 1}

Television viewing: Child Trends. (2002). Child Trends DataBank, Table 1. Hours of television watching on the average weekday: Eighth graders, 1991-2001. Retrieved June 13, 2003, from the World Wide Web: http://www.childtrendsdatabank.org/tables/55_Table_1.htm. Original data from Monitoring the future: A continuing study of American youth conducted by Jerald Bachman and colleagues at the Survey Research Center in the Institute for Social Research at the University of Michigan; Spanking: Straus, M. and Stewart, J. (1999). Corporal punishment by American parents: National data on prevalence, chronicity, severity, and duration, in relation to child and family characteristics. Clinical Child and Family Psychology Reviews, 2(2), 55-70; Physical 
fighting: Child Trends. (2002). Child Trends DataBank, Table 1. Physical fighting: Percentage of students in grades 9-12 who report physical fighting in the past Year. Retrieved February 14, 2003, from the World Wide Web:

http://www.childtrendsdatabank.org/tables/22_Table_1.htm. Original data from the Youth Risk Behavior Survey collected by the National Center for Chronic Disease Prevention and Health Promotion, Centers for Disease Control and Prevention; Weapons carrying: Child Trends. (2002). Child Trends DataBank, Table 1. Weapons: Percentage of high school students who carry weapons. Retrieved February 14, 2003, from the World Wide Web:

http://www.childtrendsdatabank.org/tables/19_Table_1.htm. Original data from the Youth Risk Behavior Survey collected by the National Center for Chronic Disease Prevention and Health Promotion, Centers for Disease Control and Prevention; Domestic violence: Straus, M. Gelles, R., and Steinmetz, S. (1980). Behind closed doors: Violence in the American family. Garden City, NY: Anchor Press. As cited in Fantuzzo, J. and Mohr, W. (1999). Prevalence and effects of child exposure to domestic violence. The Future of Children, 9(3), 21-32; Straus, M (1992). Children as witnesses to marital violence: A risk factor for lifelong problems among a nationally representative sample of American men and women. Report of the 23rd Ross Roundtable. Columbus, $\mathrm{OH}$ Ross Laboratories. From the World Wide Web:

http://pubpages.unh.edu/ mas2/VB48.pdf; Teen suicide attempts Child Trends. (2002). Child Trends DataBank indicator: Suicidal teens. Retrieved February 14, 2003, from the World Wide Web:

http://www.childtrendsdatabank.org/health/mental/34SuicidalTeens.ht m. Original data from the Youth Risk Behavior Survey collected by the National Center for Chronic Disease Prevention and Health Promotion, Centers for Disease Control and Prevention; Bullying and fear of attack at school: DeVoe, J. F., Peter, K., Kaufman, P., Ruddy, S.A. Miller, A.K., Planty, M., Snyder, T.D., Duhart, D.T., and Rand, M.R. (2002). Indicators of school crime and safety (NCES 2003-009/NCJ 196753). Washington, DC: U.S. Departments of Education and Justice. Tables 12.1 and 6.1; Violent crime victimization (all ages): Child Trends. (2002). Child Trends DataBank, Table 1. Violent crime victimization rates, ages 12-19. Retrieved February 14, 2003, from the World Wide Web: http://www.childtrendsdatabank.org/tables/71 Table 1.htm. Original data from the National Crime Victimization Survey administered by the U.S. Census Bureau on behalf of the U.S. Department of Justice; Child maltreatment and sexual abuse: Child maltreatment 2001. (2003). Washington, DC: U.S. Department of Health and Human Services, Administration on Children, Youth and Families. Tables 3.3 and 3.5; Teen firearm death, homicide, and suicide: Child Trends (2002). Child Trends DataBank, Table 1. Homicide, suicide, and firearm death among youth ages 15-19. Retrieved February 14, 2003, from the World Wide Web:

http://www.childtrendsdatabank.org/tables/70 Table 1.htm. Original data from the National vital statistics system administered by the National Center for Health Statistics, Centers for Disease Control and Prevention; Infant homicide: Child Trends. (2002). Child Trends DataBank, Table 1. Homicide rates for infants under 1 years. Retrieved April 11, 2003, from the World Wide Web: http://www.childtrendsdatabank.org/tables/72_Table_1.htm. Original data from the National vita statistics system administered by the National Center for Health Statistics, Centers for Disease Control and Prevention.

\section{Table 2}

Aggravated assault: U.S. Department of Justice. (2003). Criminal victimization in the United States, 2001-- Statistical Tables. (NCJ 197064). Table 9. From the World Wide Web:

http://www.ojp.usdoj.gov/bjs/pub/pdf/cvus01.pdf; Homicide and suicide: Anderson, R. (2002). Deaths: Leading causes for 2000. 50 (16). Hyattsville, Maryland: National Center for Health Statistics. Table 1. From the World Wide Web:

http://www.cdc.gov/nchs/data/nvsr/nvsr50/nvsr50_16.pdf; TV watching: Child Trends. (2002). Child Trends DataBank indicator: watching television. Retrieved June 9, 2003, from the World Wide Web:www.childtrendsdatabank.org/eduskills/behaviors/55WatchingTV. htm. Original data from Monitoring the future: A continuing study of American youth conducted by Jerald Bachman and colleagues at the Survey Research Center in the Institute for Social Research at the University of Michigan; Abuse and neglect: Child maltreatment 1999. (2001). Washington, DC: U.S. Government Printing Office. Table 2-10. From World Wide Web: http://www.acf.dhhs.gov/programs/cb/publications/cm99/.
ENDNOTES

${ }^{1}$ David Finkelhor has developed a similar typology of violence and victimization in children's lives that includes the classifications pandemic, acute, and extraordinary. See Finkelhor, D., and Hashima, P. (2001). The victimization of children and youth: A comprehensive overview. In White, Handbook of youth and justice. New York: Klewer Academic Press/Plenum Publishers. http://www.unh.edu/ccrc/pdf/Chap4.pdf.

${ }^{2}$ Child Trends. (2002). Child Trends DataBank indicator: Watching television. Retrieved April 16, 2003, from the World Wide Web: http://www.childtrendsdatabank.org/eduskills/behaviors/55WatchingTV .htm. Original data from Monitoring the future: A continuing study of American youth conducted by Jerald Bachman and colleagues at the Survey Research Center in the Institute for Social Research at the University of Michigan.

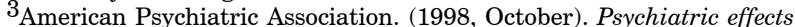
of media violence. Retrieved February 28, 2003, from the World Wide Web: http://www.psych.org/public info/media violence.cfm, as found in Osofsky, J. D. (1999). The impact of violence on children. The Future of Children, 9(3), 33-49.

${ }^{4}$ National Association for the Education of Young Children. (1997) Early years are learning years: media violence and young children. Retrieved April 24, 2003, from the World Wide Web: http://npin.org/library/pre1998/n00154/n00154.html.

${ }^{5}$ American Academy of Pediatrics, Committee on Public Education. (2001). Media violence. Pediatrics, 108(5), 1222-1226.

${ }^{6}$ Huesmann, L. R., Moise-Titus, J., Podolski, C., and Eron, L. D. (2003) Longitudinal relations between children's exposure to TV violence and their aggressive and violent behavior in young adulthood: 1977-1992. Developmental Psychology, 39(2), 201-221. From the World Wide Web: www.apa.org/journals/dev/press_releases/march_2003/dev392201.pdf. ${ }^{7}$ Child Trends. (2002). Child Trends DataBank indicator: Physical fighting by youth. Retrieved April 16, 2003, from the World Wide Web: http://www.childtrendsdatabank.org/health/violence/22PhysicalFightin g.htm. Original data from the Youth Risk Behavior Survey collected by the National Center for Chronic Disease Prevention and Health Promotion, Centers for Disease Control and Prevention.

${ }^{8}$ Centers for Disease Control and Prevention. (2002). Youth Risk Behavior Surveillance, 2001. MMWR 2002; 51(SS-4): Table 8. Centers for Disease Control and Prevention. (2002).

http://www.cdc.gov/mmwr/preview/mmwrhtml/ss5104a1.htm\#tab8. ${ }^{9}$ Ibid

${ }^{10}$ Child Trends. (2002). Child Trends DataBank indicator: Attitudes towards spanking. Retrieved April 6, 2003, from the World Wide Web: http://www.childtrendsdatabank.org/family/thefamily/51AttitudesTowa rdsSpanking.htm. Original data from the General Social Survey administered by the National Opinion Research Center at the University of Chicago.

${ }^{11}$ Straus, M. and Stewart, J. (1999). Corporal punishment by American parents: National data on prevalence, chronicity, severity, and duration, in relation to child and family characteristics. Clinical Child and Family Psychology Reviews, 2(2), 55-70.

12 Straus, M., Hamby, S., Finkelhor, D., Moore, D., and Runyan, D. (1998). Identification of child maltreatment with the parent-child conflict tactics scales: development and psychometric data for a national sample of American parents. Child Abuse and Neglect. Vol. 22, No. 4 ., pp 249-270. Table 1. From the World Wide Web:

http://pubpages.unh.edu/ mas2/CTS17.pdf

${ }^{13}$ Gershoff, E.T. (2002) Corporal punishment by parents and associated child behaviors and experiences: A meta-analytic and theoretical review. Psychological Bulletin, 128(4), 539-579.

${ }^{14}$ Straus, M. (2001). New evidence for the benefits of never spanking. Society. (September/October).

${ }_{15}$ Baumrind, D., Larzelere, R., and Cowan, P. (2002). Ordinary physical punishment: Is it harmful? Comment on Gershoff (2002). Psychological Bulletin. 128(4), 580-589.

${ }^{16}$ Centers for Disease Control and Prevention. (2002). Youth Risk Behavior Surveillance, 2001. MMWR 2002; 51(SS-4): Tables 6 and 10. http://www.cdc.gov/mmwr/preview/mmwrhtml/ss5104a1.htm\#tab6.

${ }^{17}$ Child Trends. (2002). Child Trends DataBank indicator: Suicidal teens. Tables 1 and 2. Retrieved February 14, 2003, from the World Wide Web:

www.childtrendsdatabank.org/health/mental/34SuicidalTeens.htm. Original data from the Youth Risk Behavior Survey collected by the National Center for Chronic Disease Prevention and Health Promotion, Centers for Disease Control and Prevention.

${ }^{18}$ Child Trends. (2002). Child Trends DataBank, Table 1. Homicide, suicide, and firearm death among youth ages 15-19. Retrieved February 14, 2003, from the World Wide Web:

http://www.childtrendsdatabank.org/tables/70_Table_1.htm. Original data from the National Vital Statistics System administered by the National Center for Health Statistics, Centers for Disease Control and Prevention.

19 Ibid.

${ }^{20}$ Centers for Disease Control and Prevention. Web-based injury statistics query and reporting system (WISQARS) [Online]. (2003). National 
Center for Injury Prevention and Control, Centers for Disease Control and Prevention (producer). Available from URL:

http://www.cdc.gov/ncipc/wisqars/.

${ }^{21}$ Child Trends. (2002). Child Trends DataBank Indicator: Infant Homicide. Retrieved February 1, 2003, from the World Wide Web: www.childtrendsdatabank.org/demo/death/72InfantHomicide.htm. Original data from the National Vital Statistics System administered by the National Center for Health Statistics, Centers for Disease Control and Prevention.

22 Arias, E. and Smith, B. (2003). Deaths: Preliminary data for 2001. National Vital Statistics Reports: 51(5). Hyattsville, MD: National Center for Health Statistics. Table 6.

http://www.cdc.gov/nchs/data/nvsr/nvsr51/nvsr51_05.pdf.

${ }^{23}$ Child Trends. (2002). Child Trends DataBank indicator: Teen homicide, suicide, and firearm death. Retrieved February 1, 2003, from the World Wide Web: http://www.childtrendsdatabank.org/health/violence/70ViolentDeath.htm. Original data from the National Vital Statistics System administered by the National Center for Health Statistics, Centers for Disease Control and Prevention.

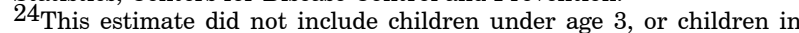
divorced families. Straus, M., Gelles, R., and Steinmetz, S. (1980). Behind closed doors: Violence in the American family. Garden City, NY Anchor Press. As cited in Fantuzzo, J. and Mohr, W. (1999). Prevalence and effects of child exposure to domestic violence. The Future of Children, 9(3), 21-32.

25 Straus, M. (1992). Children as witnesses to marital violence: A risk factor for lifelong problems among a nationally representative sample of American men and women. Report of the 23rd Ross Roundtable. Columbus, OH: Ross Laboratories. From the World Wide Web:

http://pubpages.unh.edu/ mas2/VB48.pdf.

26 Fantuzzo, J. and Mohr, W. (1999). Prevalence and effects of child exposure to domestic violence. The Future of Children, 9(3), 21-32.26

27 Schechter, S. and Edleson, J.L. (2000). Domestic violence and children: Creating a public response. Center on Crime, Communities and Culture for the Open Society Institute.

${ }^{28}$ Whitfield, C., Anda, R., Dube, S., and Felitti, V. (2003). Violent childhood experiences and the risk of intimate partner violence as adults. Journal of Interpersonal Violence, 18(12).

${ }^{29}$ Child maltreatment 2001. (2003). Washington, DC: U.S. Department of Health and Human Services, Administration on Children, Youth and Families. From the World Wide Web:

http://www.acf.hhs.gov/programs/cb/publications/cmreports.htm.

30 Child Trends. (2002). Charting parenthood: A statistical portrait of fathers and mothers in America. Page 24. Washington, D.C.: Child Trends. The survey in question is the 1995 Gallup Survey on Disciplining Children in America.

31 For a summary of the consequences of child maltreatment, see Chalk, R., Gibbons, A. and Scarupa, H. (2002). The multiple dimensions of child abuse and neglect: New insights into an old problem. Child Trends Research Brief. Washington, DC: Child Trends. http://www.childtrends.org/PDF/ChildAbuseRB.pdf

${ }^{32}$ Child maltreatment 2001. (2003). Table 3-5.

33 As Finkelhor points out, sexual abuse, as commonly used, often refers to acts committed by caretakers. Sexual assault, on the other hand, includes a wider array of attackers (though non-assaultive sexual crimes are sometimes excluded). For more, see Finkelhor, D., and Hashima, P. (2001). The victimization of children and youth: A comprehensive overview. In White, Handbook of Youth and Justice. New York: Klewer Academic Press/Plenum Publishers. 51-52.

http://www.unh.edu/ccrc/pdf/Chap4.pdf.

34 Child Trends. (2002). Child Trends DataBank indicator: Adolescents who have ever been raped. Retrieved April 16, 2003, from URL:

http://www.childtrendsdatabank.org/health/violence/31Rape.htm. Original data from the Youth Risk Behavior Survey collected by the National Center for Chronic Disease Prevention and Health Promotion, Centers for Disease Control and Prevention.

35PsycNET, American Psychological Association. (2001).

Understanding child sexual abuse: Education, prevention, and recovery. Retrieved February 12, 2003, from the World Wide Web:

http://www.apa.org/releases/sexabuse/effects.html.

36 National Center for Injury Prevention and Control, Centers for Disease Control and Prevention. (2000, February 10). Rape fact sheet Retrieved December 27, 2002, from the World Wide Web: http://www.cdc.gov/ncipc/factsheets/rape.htm.

37 Child Trends. (2002). Child Trends DataBank indicator: Violent crime victimization. Retrieved April 16, 2003

from the World Wide Web:

http://www.childtrendsdatabank.org/health/violence/71ViolentVictimiz ation.htm. Original data from the National Crime Victimization Survey administered by the U.S. Census Bureau on behalf of the U.S.

Department of Justice.

38 Note that females ages 12-15 have somewhat higher rates and males ages 16-17 have somewhat lower rates of being reported as victims of physical abuse than younger children. See Child maltreatment 2000. (2002). Table 3-10. Washington, DC: U.S. Department of Health and
Human Services, Administration on Children, Youth and Families.

${ }^{39}$ Johnson, C. F. (2002). Physical abuse: Accidental versus intentional trauma in children. In Myers, J., Berliner, L., Briere, C., Hendrix, C. Jenny, and T. Reid (Ed.), The APSAC Handbook on Child Maltreatment: Second Edition (pp. 256): Sage Publications.

${ }^{40}$ Paulozzi, L., \& Sells, M. (2002). Variation in homicide risk during infancy - United States, 1989-1998. Morbidity and Mortality Weekly Report, 51(09): 187-189. Centers for Disease Control and Prevention. From the World Wide Web:

www.cdc.gov $/ \mathrm{mmwr} / \mathrm{preview} / \mathrm{mmwrhtml} / \mathrm{mm} 5109 \mathrm{a} 3 . \mathrm{htm}$

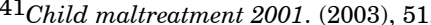

42 Ibid, 47

43Fantuzzo, J., and Mohr, W. (1999).

${ }^{44}$ Presentation by David Wolfe at NICHD Workshop on Children Exposed to Violence, July 24-26, 2002. In Workshop on children exposed to violence: Current status, gaps, and research priorities. Workshop Summary prepared by Analytical Sciences. From the World Wide Web: http://www.nichd.nih.gov/crmc/cdb/Workshop_on_ChildrenViolence.pdf ${ }^{45}$ Straus, M., and Stewart, J. (1999).

${ }_{46}$ Kaiser Family Foundation. (1999). Kids and media at the new millennium: A comprehensive analysis of children's media use. From the World Wide Web:

http://www.kff.org/content/1999/1535/KidsExecSum\%20FINAL.pdf. 47 Ibid, p21.

${ }^{48}$ Child maltreatment 2000. (2002). Table 3-10.

${ }^{49}$ Web-based injury statistics query and reporting system (WISQARS) [Online]. (2003). Available from URL:

http://www.cdc.gov/ncipc/wisqars/.

DeVoe, J. F., Peter, K., Kaufman, P, Ruddy, S.A., Miller, A.K, Planty, M., Snyder, T.D., Duhart, D.T., and Rand, M.R. (2002). Indicators of school crime and safety 2002 (NCES 2003-009/NCJ

196753). Table 6.1. Washington, DC: 2002.: U.S. Departments of

Education and Justice. From the World Wide Web:

http://www.ojp.usdoj.gov/bjs/abstract/iscs02.htm.

51 Child Trends. (2002). Child Trends DataBank indicator: Youth who feel unsafe at school. Retrieved June 12, 2003, from the World Wide

Web:

http://www.childtrendsdatabank.org/health/violence/38UnsafeatSchool. htm\#top. Original data from the School Crime Supplement to the National Crime Victimization Survey administered by the U.S. Census Bureau on behalf of the U.S. Department of Justice, Bureau of Justice Statistics.

${ }^{2}$ Web-based injury statistics query and reporting system (WISQARS) [Online]. (2003). Available from URL:

http://www.cdc.gov/ncipc/wisqars/.

${ }^{53}$ Child Trends DataBank indicator: Violent crime victimization. (2002) http://www.childtrendsdatabank.org/health/violence/71ViolentVictimiz ation.htm

${ }^{54}$ Child Trends. (2002). Child Trends DataBank indicator: Students carrying weapons. Retrieved April 16, 2003, from the World Wide Web: http://www.childtrendsdatabank.org/health/violence/19StudentsCarryi ngWeapons.htm. Original data from the Youth Risk Behavior Survey collected by the National Center for Chronic Disease Prevention and Health Promotion, Centers for Disease Control and Prevention.

${ }^{55}$ Child Trends. (2002). Child Trends DataBank indicator: Dating violence. Retrieved April 16, 2003, from the World Wide Web: http://www.childtrendsdatabank.org/health/violence/66DatingViolence. htm. Original data from the Youth Risk Behavior Survey collected by the National Center for Chronic Disease Prevention and Health Promotion, Centers for Disease Control and Prevention.

56 Ibid.

57 DeVoe, J.F., et al. (2002). Table 12.1.

${ }^{58}$ Child Trends. (2002). Child Trends DataBank indicator: Physical fighting by youth. http://www.childtrendsdatabank.org/health/violence/22PhysicalFighting.htm.

${ }^{59}$ Child maltreatment 2000. (2002). Table 3-10.

60 Straus, M., and Stewart, J. (1999).

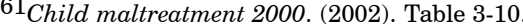

${ }^{62}$ Child Trends. (2002). Child Trends DataBank indicator: Adolescents who have ever been raped.

http://www.childtrendsdatabank.org/health/violence/31Rape.htm.

63 Child maltreatment 2000. (2002). Table 3-10.

${ }^{64}$ Child Trends DataBank indicator: Suicidal teens.(2002).

http://www.childtrendsdatabank.org/health/mental/34SuicidalTeens.htm.

${ }^{65}$ Child Trends DataBank indicator: Dating violence. (2002). http://www.childtrendsdatabank.org/health/violence/66DatingViolence. htm

66 U.S. Department of Justice and Centers for Disease Control and Prevention. (1998, November). Prevalence, incidence, and consequences of violence against women: Findings from the National Violence Against Women Survey. From the World Wide Web: http://ncjrs.org/pdffiles/172837.pdf.

67 Web-based injury statistics query and reporting system (WISQARS) [Online]. (2003). vailable from URL:

http://www.cdc.gov/ncipc/wisqars/. 
${ }^{68}$ Child Trends DataBank indicator: Teen homicide, suicide, and firearm death. (2002). http://www.childtrendsdatabank.org/health/violence/70ViolentDeath.htm.

${ }^{69}$ Child Trends DataBank indicator: Students carrying weapons.

(2002).

http://www.childtrendsdatabank.org/health/violence/19StudentsCarryi ngWeapons.htm.

${ }^{70}$ Child Trends DataBank indicator: Physical fighting by youth. (2002). http://www.childtrendsdatabank.org/health/violence/22PhysicalFightin g.htm.

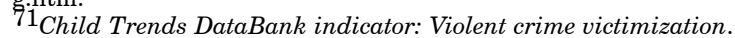

(2002).

http://www.childtrendsdatabank.org/health/violence/71ViolentVictimiz ation.htm.

72 Child maltreatment 2000. (2002). Table 3-10.

${ }^{73}$ DeVoe, J. F., et al. (2002). Tables 6.1 and 12.1 .

${ }^{74}$ Child Trends DataBank indicator: Infant homicide. (2002). www.childtrendsdatabank.org/demo/death/72InfantHomicide.htm.

75 Anderson, R. (2002). Deaths: Leading causes for 2000. (50)16. Hyattsville, Maryland: National Center for Health Statistics. Tables 1 and 2. From the World Wide Web:

http://www.cdc.gov/nchs/data/nvsr/nvsr50/nvsr50_16.pdf.

${ }^{76}$ Child Trends DataBank indicator: Teen homicide, suicide, and firearm death. (2002).

http://www.childtrendsdatabank.org/health/violence/70ViolentDeath.htm.

77 Chalk, R., Gibbons, A., and Scarupa, H. (2002).

${ }^{78}$ Child Trends (2002). Charting parenthood: A statistical portrait of fathers and mothers in America.

${ }^{79}$ Note: Estimates were available for white youth and black youth only. Source: Child Trends DataBank Indicator: Violent Crime Victimization (2002).

$\mathrm{http}: /$ www.childtrendsdatabank.org/health/violence/71ViolentVictimization.htm ${ }^{80}$ Child Trends DataBank indicator: Watching television. (2002). http://www.childtrendsdatabank.org/eduskills/behaviors/55WatchingTV.htm. ${ }^{81}$ Child Trends DataBank indicator: Physical fighting by youth. (2002). http://www.childtrendsdatabank.org/health/violence/22PhysicalFighting.htm.

${ }^{82}$ Child Trends DataBank indicator: Teen homicide, suicide, and firearm death. (2002).

http://www.childtrendsdatabank.org/health/violence/70ViolentDeath.htm.

${ }^{83}$ Hawkins, J.D., Herrenkohl, D.P., Farrington, D.B., Catalano, R.F., Harachi, T.W., and Cothern, L. (2000). Predictors of Youth Violence. Office of Juvenile Justice and Delinquency Prevention, U.S Department of Justice. http://www.ncjrs.org/pdffiles1/ojjdp/179065.pdf. ${ }^{84}$ See Hawkins et. al., 2000.

${ }^{85}$ See Hawkins et. al., 2000. See also Maxfield, M., and Widom, C., (1996). The cycle of violence, revisited 6 years later. The Archives of Pediatric and Adolescent Medicine. 150, 390-395. 